\title{
The second image reversed: the international sources of domestic politics
}

Peter Gourevitch

Is the traditional distinction between international relations and domestic politics dead? Perhaps. Asking the question presupposes that it once fit reality, which is dubious. Nonetheless, the two branches of political science have at the very least differing sensibilities. Each may look at the same subject matter without asking the same questions. The international relations specialist wants to explain foreign policy and international politics. He cares about the domestic system insofar as it is useful for that purpose. He may, if dissatisfied with pure international system explanations, make his own exploration into domestic politics, a voyage which can frequently bring back discoveries (such as Allison's Essence of Decision') most useful to the comparativists. Still, the ultimate goal of the trip remains the understanding of international dynamics. Domestic structure for the "I.R." person is an independent or intervening variable and sometimes an irrelevant one. ${ }^{2}$ Most of the literature concerned with the interaction of the international system and domestic structure is authored by writers with international concerns, and that literature therefore primarily looks at the arrows that flow from domestic structure toward international relations.

A comparativist often seeks to explain the nature of the domestic structure: why it is as it is, how it got that way, why one structure differs from another, how it affects various aspects of life, such as health, housing, income distribution, economic growth and so on. To answer such questions, the international system may

The author wishes to acknowledge the assistance of David Bloom, Lisa Hirschman, Stanley Hoffmann, Miles Kahler, Peter Katzenstein, James Kurth, Janice Stein, and the editors of International Organization.

'Graham Allison, Essence of Decision (Boston: Little Brown, 1971).

"Kenneth Waltz, "Theory of International Relations," in Fred Greenstein and Nelson Polsby, eds., Handbook of Political Science: International Relations (Menlo Park: Addison-Wesley, 1975), vol. 8, pp. $1-86$.

International Organization 32,4, Autumn 1978

$0020-8183 / 78 / 0004-0881 \$ 01.00 / 0$

(C) 1978 by the Regents of the University of Wisconsin System 
itself become an explanatory variable. Instead of being a cause of international politics, domestic structure may be a consequence of it. International systems, too, become causes instead of consequences.

Like others working in these fields, I am interested in the questions posed by both sensibilities. In this essay, however, I wish to concentrate on those posed by the comparativist. We all know about interaction; we all understand that international politics and domestic structures affect each other. Having recently read, for a variety of purposes, much of the current literature which explores this interaction, I think the comparativist's perspective has been neglected, that is, the reasoning from international system to domestic structure. I offer comment and criticism of that literature in three interrelated domains:

First, in using domestic structure as a variable in explaining foreign policy, we must explore the extent to which that structure itself derives from the exigencies of the international system. As a contribution to such exploration, I will examine a variety of arguments found in diverse writings which seek to do this.

Second, in using domestic structure as a variable for explaining foreign policy, much of the literature is "apolitical." It stresses structural features of domestic regimes which constrain policy regardless of the content of the interests seeking goals through public policy or the political orientation of the persons in control of the state machine. I will examine this problem through a brief discussion of the distinction often made between "strong" and "weak" states as an explanation of foreign economic policy.

Finally, in exploring the links between domestic and international politics much of the literature argues that a break with the past has occurred such that the present character of the interaction represents a discontinuity which requires new categories of analysis. In particular, much is made of interdependence, permeability, transnational actors, and the decline of sovereignty. While it is certain that the present is not identical to the past, this claim for newness is overstated. Many features which are considered characteristic of the present (interdependence, the role of trade, transnational actors, permeability, conflict within the state over desirable policy) also seem relevant to past systems and regimes; and conversely, characteristics of the past (war, instability, sovereignty, military power, international anarchy) seem to be still with us.

The bulk of the paper deals with the first point. The other two are handled all too briefly and tentatively. I place them all together, at the risk of overburdening the reader, because I wish to show that there is some reward for the international relations specialists interested in the second and third points who are willing to undertake the voyage of looking at the first. Treating them together will compel us to think differently about the linkage between international relations and domestic politics.

\section{Part one: the impact of the international system on domestic politics}

Two aspects of the international system have powerful effects upon the character of domestic regimes: the distribution of power among states, or the international 
state system; and the distribution of economic activity and wealth, or the international economy. Put more simply, political development is shaped by war and trade.

These two categories are certainly not exhaustive. Other external forces exist. Ideas or ideology, for example, can make a great difference to political development: Catholic vs. Protestant; Napoleon and the French Revolution vs. the Ancien Regime; fascism, communism and bourgeois democracy against each other. These lines of ideological tension shaped not only the international system but internal politics as well. This should be no surprise. Ideas, along with war and trade, relate intimately to the critical functions any regime must perform: defense against invaders, satisfaction of material want, gratification of ideal needs. ${ }^{3}$

Of course, the clearest form of external influence on politics is outright invasion and occupation, though occupation can be complex, as it usually requires native collaborators. Less clear empirically but equally obvious conceptually is "meddling": subsidies to newspapers or to fifth columns, spying, assassination, and so on. Neither of these categories requires much investigation. We need not look very far to find examples of regimes altered by the arrival of foreign troops: Germany after both World Wars, Italy in 1943, Austria-Hungary in 1918, Hungary in 1956, Czechoslovakia in 1968. Nor is it hard to find cases of meddling: Iran in 1954, Guatemala in the same year, Chile in 1973, Vietnam since World War II. The role of ideas requires careful consideration, but for reasons of space and mental economy, I shall limit my discussion to the international state system and the international economy.

Similarly, I shall limit the range of outcomes to be explored. "Impact on domestic politics" could include a variety of effects: specific events, specific decisions, a policy, regime type, and coalition pattern. It is not hard to think of examples of the first three: the Zinoviev letter and the British election of 1924; the United States declaration of war after Pearl Harbor; the rise of world tariff levels after the price drop beginning in 1873. I shall focus here on the more complex outcomes. First, regime type: constitutionalist or authoritarian; bourgeois democratic or fascist or communist; monarchic or aristocratic or democratic; liberal or totalitarian; effective or debile; unitary or federal; presidential or parliamentary. Second, coalition pattern: type and mix of dominant elites: property owners or political elites, or army or finance or manufacturing or trade unionists; integrated, autonomous or radical working class movements; narrowly held power or broadly shared power. Regime type and coalition pattern are certainly interconnected and it is not easy to sustain neatly the distinction. By the former I wish to evoke institutional structure, the machinery, process and procedures of decision making; by the latter I wish to evoke social forces and the political relationships among them. The latter has to do with what the groups are and what they want; the former stresses the formal properties of the links among them. These are the more significant outcomes for our purposes because they constitute enduring features of a given political system, ones which operate over time to shape behavior at specific moments of decision, events, or policy formation. Regime type and coalition pattern are the properties of a political system most often used as a variable for the explanation of foreign policy. These 
different external forces and the outcomes they produce are presented in tabular form in the appendix. The remainder of the first section looks at arguments suggesting the impact of two types of international stimulus on the formation of regime type and coalition pattern: the economy and the international state system.

\section{The international economy}

Recent events and the international relations literature have made us acutely aware of the impact of world market forces upon domestic politics. Citing the oil embargo after the Arab-Israeli war of 1973 makes other examples unnecessary. These effects though are not something new. The Great Depression alone did not bring Hitler to power: German history, institutions, parties, political culture, classes and key individuals did that, but it is impossible to imagine that without the millions thrown out of work by the contraction of the United States economy following the Crash of 1929 these other forces could have brought the result about.

The economic cycle referred to as the Great Depression of 1873-96 also had dramatic effects on political life around the world. Immense increases in agricultural and industrial production caused the prices of both sorts of goods to plummet. In Britain, the flood of foreign grain drove many persons off the land, undermined the landed aristocracy, and hastened democratization of political life (the secret ballot, universal suffrage, elected local government, disestablishment of the Church). In France and Germany, the drop in prices threatened landed and industrial interests. In both countries, these groups managed to protect themselves by erecting high tariff barriers. In France, this served to strengthen the Republic. In Germany, it stabilized Bismarck's newly-fashioned ramshackle empire. In both countries, preindustrial groups were thereby able to prolong their positions with ultimately disastrous consequences for constitutional government: fascism in Germany, the French collapse in the thirties and Vichy afterwards. Italy, Russia and Southeastern Europe could no longer provide even subsistence to much of their populations and sent a tidal wave of migrants around the world. In America, the late nineteenth century depression spawned Populism, a most powerful challenge to the two-party system and to the hegemony of industrial interests. It was ultimately defeated in part because the immigrants hurled ashore by the crisis in Europe sided with their Republican employers against the Populist and Democratic farmers. ${ }^{4}$

In all these countries, what we now call transnational actors were certainly present (at least in some sense of that term) ${ }^{5}$ : British investors, German steel manufacturers, French engineers, American missionaries.

That international market forces affect politics and have done so for a long time seems incontrovertible. Can we find general arguments which posit systematic relationships between such forces and certain configurations of regime type and coalition pattern?

"Peter Gourevitch, "International Trade, Domestic Coalitions and Liberty: Comparative Responses to the Crisis of 1873-1896," Journal of Interdisciplinary History, VIII: 2 (Autumn 1977): 281-313.

sSamuel Huntington, "Transnational Organizations," World Politics, 25 (April 1973): 338-368. 


\section{Late industrialization and centralized state control}

One of the most well-known of these is Alexander Gerschenkron's famous essay "Economic Backwardness in Historical Perspective." ${ }^{6}$ Gerschenkron's argument goes, briefly, as follows: the economic and political requirements of countries which industrialize early, when they have few competitors and simple, lowcapital technology, are different from the requirements of those which industrialize when competition already exists and industry has become highly complex, massive, and expensive. The more advanced the world economy, the greater the entry costs. Paying those costs requires greater collective mobilization, which in turn requires greater central coordination. Societies which, prior to industrialization, developed strong central institutions will find these institutions useful if they attempt to catch up with "early" industrializers.

The first industrializer, Britain, enjoyed a congruence between the liberal character of its society and the relatively simple nature of economic development in the first stage of the industrial revolution in the eighteenth century. The society had weak or nonexistent guilds which were unable to prevent the introduction of new practices. It had an abundant labor supply to be pulled off the land into factories and a commercially oriented aristocracy and middle class, both with sharp eyes for new ways for finding profits. Its navy was able to corral world markets. Its state was strong enough to support that navy and to maintain order at home, without curtailing adventuresomeness and profit seeking even when, as with enclosures, these threatened social stability. Industry was at the textile stage, in its first incarnation: innovation was small-scale, relatively individualistic, and dependent on artisans; capital requirements and organizational requirements were low and easily mobilized by market forces. ${ }^{7}$

In the eighteenth century, German society could not imitate this model. Political fragmentation limited demand-pull. Strong guilds inhibited innovation. The regime in the land across what became Germany varied considerably, but in most parts, the peasants, while lacking the freedoms of their English counterparts, could nevertheless not be driven off it. The middle class was of a traditional composition: lawyers, civil servants, teachers, traders, all little inclined toward industrial innovation. The aristocracy varied considerably. In the east the gentry were profitoriented, but sought to make their money from the land and related activities such as brewing, and were quite disinclined to invest in new activities which might threaten the hegemony of farming. While the German state did not exist, local ones did.

\footnotetext{
'Alexander Gerschenkron, "Economic Backwardness in Historical Perspective," in Economic Backwardness in Historical Perspective (Cambridge: Harvard U.P., 1963). See James Kurth's very brilliant extension of Gershenkron, combining his with other lines of reasoning, "The Political Consequences of the Product Cycle: Industrial History and Comparative Politics," International Organization (forthcoming) and his equally brilliant essay "Delayed Development and European Politics" (mimeo, 1977) part of which will appear as an essay in a forthcoming volume on Latin America, edited by David Collier, sponsored by the Joint Committee on Latin American Studies of the Social Science Research Council.

${ }^{7}$ E.J. Hobsbawm, Lndustry and Empire (Baltimore: Penguin, 1970); D.J. Landes, The Unbound Prometheus (Oxford: Oxford U.P., 1969).
} 
These had very strong traditions of state activity, especially state-directed economic activity. ${ }^{8}$

Over a century later, some of these liabilities became advantages. When the industrial revolution moved from textiles to iron and steel to chemicals, from putting-out small spinning jennys and handlooms to gigantic factories, blast furnaces, mines and so on, capital requirements skyrocketed. Organization and coordination became critical components of productivity. The corporate character of German society, at first a hindrance, now became a help. Once a certain level of technology was reached, it was no longer necessary to become like England in order to copy her. Banks and the state organized very rapid industrialization in a highly centralized way without parallel in Britain. This sort of centralized state corporatism was strongly rewarded by international markets. Germany surged ahead of Britain by the turn of the century.

While Gerschenkron's article deals only with the late nineteenth century, it is possible to extend the argument quite widely. Barrington Moore does so in suggesting that bourgeois democracy, fascism, and communism are successive modes of modernization, rather than options available to any given country at a particular moment. Moore ties the consequences of "lateness" more explicitly to fascism. The very configuration which made it possible for Germany and Japan, and to a lesser extent Italy, to catch up to Britain so rapidly (the survival of classes, institutions, and values from a preindustrial, anticonstitutionalist era), also made those countries more vulnerable to fascism. Moore then extrapolates to the peasant-based revolutions of Russia and China: by the time they were drawn into the world system of states and competition, things had proceeded even farther: even the GermanJapanese model was no longer appropriate. The landlord-industrialist-bureaucrat alliance was too weak in relation to the peasantry and the nascent proletariat which could be mobilized under the conditions of extreme pressure brought about by the World Wars and capitalist penetration. By the twentieth century, autonomous development required autarchy; politically the only base for securing such a policy was a mass one, requiring a disciplined party to overthrow the old elites. Moore sketches out the bones of this argument all too briefly:

To a very limited extent these three types-bourgeois revolution culminating in the Western form of democracy, conservative revolutions from above ending in fascism, and peasant revolutions leading to communism-may constitute alternative routes and choices. They are much more clearly successive historical stages. As such, they display a limited determinate relation to each other. The methods of modernization chosen in one country change the dimensions of the problem for the next countries who take the step, as Veblen recognized when he coined the now fashionable term, "the advantages of backwardness." Without the prior democratic modernization of England, the

${ }^{8} \mathrm{~F}$. Carsten, The Origins of Prussia (Oxford: Clarendon Press, 1968); T. Hamerow, Revolution, Restoration, Reaction (Princeton: Princeton U.P., 1958); J.H. Clapham, Economic Development of France and Germany, 4th edition (Cambridge: Cambridge U.P., 1935). 
reactionary methods adopted in Germany and Japan would scarcely have been possible. Without both the capitalist and reactionary experiences, the communist method would have been something entirely different, if it had come into existence at all.... Although there have been certain common problems in the construction of industrial societies, the task remains a continually changing one. The historical preconditions of each major political species differ sharply from the others. ${ }^{9}$

Gerschenkron's ideas have also found resonance in studies of Latin America. Albert Hirschman, in a well-known article on import-substituting industrialization, finds both parallels and differences between Latin America's "late late development" and the German-Japanese model: "lateness" may not correlate with vigorous growth, high concentration, and strong government in a linear way; in some respects, the curve is "backward-bending": after a certain point, lateness leads to sporadic growth, and erratic central direction. ${ }^{10}$ Drawing on Hirschman, Guillermo O'Donnell offers an explanation of the spread of dictatorship across Latin America. These 'bureaucratic authoritarian' regimes, he suggests, derive from a crisis in the import-substituting strategy of developments whose failures induce diverse pressures which in turn provoke harsh political techniques for their control. ${ }^{11}$

In some fascinating recent work on "Latin Europe," James Kurth makes a brilliant synthesis of Gershenkronian reasoning and other concepts drawn from such diverse authors as Raymond Vernon (the product cycle), Joseph Schumpeter (the epoch-making innovation), and Max Weber (types of authority), in the service of speculations about the distinctive features of politics common to Portugal, Spain, Italy, Greece and the countries of Latin America. As with other "late developers," politics in each of these countries is strongly affected by the juxtaposition of preindustrial and industrial classes; the alternation between liberal and authoritarian forms derives in part from that mixture. Unlike the "earlier" late developers, the South European countries face an even more evolved international economic structure, one in which certain forms of industrial activity are sloughed off by the most advanced countries, or more precisely, by corporations seeking lower labor costs.

\footnotetext{
${ }^{9}$ Barrington Moore, Jr., Social Origins of Dictatorship and Democracy (Boston: Little, Brown, 1966), pp. 413-44. For a critique of Moore directed at the failure to develop sufficiently an "intersocial perspective," see Theda Skocpol, "A Critical Review of Barrington Moore's Social Origins of Dictatorship and Democracy," Politics and Society (Fall 1973): 1-34.

${ }^{10}$ Albert Hirschman, "The Political Economy of Import Substituting Industrialization in Latin America," in A Bias for Hope (New Haven: Yale University Press, 1971), pp. 85-123, and "The Turn to Authoritarianism in Latin America and the Search for Its Economic Determinants," in the forthcoming volume on Latin America edited by David Collier, and "A Generalized Linkage Approach to Development, with Special Reference to Staples," Economic Development and Cultural Change, 25 (Supplement 1977): 67-98.

${ }^{11}$ Guillermo O'Donnell, Modernization and Bureaucratic Authoritarianism (Berkeley: University of California, Institute for International Studies, Politics of Modernization Series, no. 9, 1973) and "Reflections on the General Tendencies of Change in Bureaucratic-Authoritarian States," Latin American Research Review, forthcoming.
} 
The system whirls like a fast merry-go-round: Italy, Greece, Spain, or Portugal can leap on when certain types of manufacturing favor their mix of labor supply and organizational skills but they lack the matured strength to hold on for good, and consequently face the constant danger of being thrown off. This situation also constrains politics, pushing and pulling toward and away from liberalism. ${ }^{12}$

For this group of authors with whom I am associating Gerschenkron's notion of late development, political outcomes within countries are strongly affected by the character of the world economy at the time in which they attempt industrialization. Because of competition and changes in technology, each entrant into the "industrialization race" faces a new game, with altered rules. For all these authors, however, the impact of each international situation cannot be determined without knowledge of the internal character of each society. Gerschenkron showed how certain characteristics of German and Russian society became advantages as the economy changed. Moore, Hirschman, O'Donnell, and Kurth all stress internal factors as well: the character of social development at the point at which the country is drawn into the international economy. This, among other points, differentiates them from the next group, the "dependencia" or "center-periphery" theorists.

\section{Theories of dependencia, core-periphery, and imperialism}

A second group of theorists attributes even greater importance to the international political economy in shaping political development than does what I have labeled the Gerschenkronians. This diverse set of writers (who will be called the dependencia theorists, even if they are more well known in association with some other rubric, such as imperialism or core-periphery theories) strives harder to avoid "reductionism" to the level of internal politics; indeed, they may be the only group to stay at the international system level, or to come close to doing so. Like the Gerschenkronians, the dependencia theorists stress the non-repeatable nature of development, the new rules for each follower, the importance of competition. In contrast with them, though less so than the liberals, the dependencia theorists attribute less weight to purely national, internal factors such as specific historical traditions, institutions, economic forms, and politics. They are also gloomier about the possibilities and benefits of the process.

What the dependencia theorists stress is the matrix set up by the advanced capitalist countries, a system of pressures which sharply constrain, indeed, wholly determine the options available to developing countries. Since capital, organization technology, and military preponderance are in the hands of the core, the core countries are able to set the terms under which skill, capital, and markets will be provided to the periphery. The core forces others into subservience: suppliers of raw materials, purchasers of finished goods, manufacturers of whatever the core allows them to do. The developing countries are unable to allocate resources according to

\footnotetext{
${ }^{12}$ James Kurth, "Patrimonial Authority, Delayed Development, and Mediterranean Politics," American Political Science Association (New Orleans, 1973) and "Political Consequences of the Product Cycle," and "Delayed Development and European Politics."
} 
their internal needs, following some alternative vision of development. As a result they are locked into a structure where the benefits of growth accrue disproportionately to the core. Countries in the perphery develop dual economies: an expanding modern sector tied to the needs of the core, and a stagnant, miserable sector, irrelevant to the needs of international capitalism, hence abandoned and ignored.

The political consequence of this system for the periphery is some form of imperialism: outright colonialism for Lenin and Hobson, where the peripheries are ruled outright by the core powers; neocolonialism for Gunder Frank, ${ }^{13}$ where the peripheries have formal sovereignty but are in fact prisoners of a structure which they cannot affect.

None of the theorists speculates very far about how much variance in political form these relationships permit dependent regimes to have. They offer no explanations as to why some countries in the neocolonial position are more liberal than others, some more authoritarian, some civilian, some military. Generally they see a tendency toward authoritarianism in the neocolonial countries, but of two different types. Elite-based authoritarianism (with the elite of the comprador, or foreignallied, foreign-dependent variety) suppresses popular pressure for a greater share of the wealth, or for a different type of development (Brazil, Chile, Argentina, Uruguay). Popular-based authoritarianism à la Cuba mobilizes the mass support needed to withdraw from the international capitalist economy altogether and pursue a socialist or communist development strategy.

Some of the authors in this group see political consequences for the core countries as well: Hobson and Lenin, of course, saw imperialism as the export of internal conflicts-falling profits and increasing worker pressure lead the capitalists to invest overseas. Hobson thought income redistribution could solve the problem of domestic demand but doubted that it could be realized. Lenin was certain that it could not. Again, the range of variance in political forms allowed core countries is not at all clear: neither Lenin nor Hobson derives from his theories of imperialism any systematic explanation of parliamentary vs. authoritarian development.

The most ambitious attempt to derive specific political forms from the international economy is that recently offered by Immanuel Wallerstein. ${ }^{14}$ While his argument thus far has been worked out in detail only for the period 1450-1650, Wallerstein intends to apply it through to the present and is at work on the subsequent volumes. Very briefly his argument is this: the development of capitalism in the fifteenth century entailed the formation of a core, semi-periphery, and periphery. Each pole had specific political requirements. Each country had therefore to generate the forms which corresponded to its place in the system. The core economies required strong states, the peripheries weak ones, while the semi-peripheries were hybrids. Thus France and England were strong as befits the core, while Poland and pre-Great Elector Prussia were weak as befits the periphery.

\footnotetext{
${ }^{13}$ Andre Gunder Frank, Capitalism and Underdevelopment in Latin America (New York: Monthly Review Press, 1967).

${ }^{14}$ Immanuel Wallerstein, The Modern World System (New York: The Academic Press, 1974).
} 
Wallerstein's treatment is complex: it has vices and virtues about which $I$ and many others have written. ${ }^{15}$ For the purpose at hand, the importance of his discussion lies in his insistence on a "world-system" perspective. Wallerstein sees his work as a break with state-centered accounts of economic and political development. Commercialized agriculture, early manufacturing, and the factory system cannot be understood in disaggregated, national terms. From the beginning, national economies grew in interaction with each other. The analyst must seek therefore to understand the properties of the system as a whole. Differentiation is one of the central properties of that system, one which confirms the necessity of the world viewpoint since its effects can only be detected from such a perspective. For Wallerstein the very essence of capitalism lies in that sort of differentiation: the operation of market forces leads to the accentuation of differences, not their reduction. Rather slight differences at an early point may explain why one area or country rather than another takes a particular place in the system-why for example Western rather than Eastern Europe became the core. Once the system begins to articulate itself, it greatly magnifies the consequences of the early differences.

Also political differentiation must, for Wallerstein, be viewed from world system to country, not vice versa. The international system is the basic unit to be analyzed, rather than units of power which come into being from some process conceived of quite separately from the operation of the system. States are the concrete precipitates from the system, not the component units of it. Perhaps it is not accidental that this argument has been enunciated by a sociologist, rather than by a political scientist or more particularly an international relations specialist. It amply partakes of Durkheim, as well as Marx, and not, as the international relations specialist would do, of Hobbes, Rousseau, and Kant. Durkheim derives the individual from society: he is as individually differentiated from others as the society allows, according to its division of labor. Similarly, Wallerstein derives the state from the system. The international division of labor determines how much variance in political forms is allowed the component units. Position in the division of labor determines the type of form: states at the core must be strong; states at the periphery must be weak.

Wallerstein wavers from this resolute application of the world-system framework at times. When he takes up the explanation of why "coreness" requires strength, he notes that the core states needed governments capable of defending themselves militarily against rivals, of imposing themselves on certain markets and sources of materials, and of creating large uniform markets internally. The reasoning is then circular: strong states led to a core position, not a core position to strong states. That there was interaction makes sense but reduces the explanatory leverage provided by the general argument. The explanation of strength can no longer be so cleanly connected to a system-level argument. Some exploration of internal

\footnotetext{
15Peter Gourevitch, "The International System and Regime Formation: A Critical Review of Anderson and Wallerstein," Comparative Politics (April 1978): 419-438. See American Journal of Sociology 82 (March 1977) for reviews of Anderson by Michael Hechter and Wallerstein by Theda Skocpol, and my review for a large number of other citations.
} 
dynamics becomes indispensable, which pushes us back to the Gerschenkronian camp. From the world-system point of view, it is hard to see why certain countries diverge politically: why, for example, Poland and Prussia become bywords for weak and strong states respectively while having very similar economic systems and similar positions in the international division of labor. And why Holland, Britain, and France were so different in the seventeenth century, when all were part of the core. Again, the answer directs us back to domestic politics, about which I will say more in the next section of the paper.

In order to dramatize the differences, I have focused on dependencia theorists who stress heavily international constraints. Not all writers associated with that school do so to an equal degree. To the extent that dependencia theorists pay attention to internal forces in explaining regime type and the Gershenkronians stress external ones, the boundary between the two camps disintegrates. Ferdinand Enrique Cardoso perhaps best exemplifies the juncture of these two modes of reasoning. ${ }^{16}$

\section{The liberal development school}

Liberal theories of economic development offer a very apolitical analysis in some ways. They also attribute considerable importance to the international economy. The relatively free play of world market forces promotes growth and wealth for the investors and recipients alike. As a country is drawn into the world economy, the laws of supply and demand and comparative advantage initially give it the "supplier-buyer" role suggested by the previous groups of theorists. But the country does not remain there. Foreign capital touches off a series of reactions leading to ever higher levels of industrialization. There are no inherent obstacles to the realization of parity or "maturity." The interaction of two unequal bodies leads eventually to their homogenization, to the elimination of the inequality; this is, as Michael Hechter has aptly analyzed, a "diffusion theory." 17

In sharp contrast with the Gerschenkronians and the dependencia theorists, the liberals treat all development trajectories as similar. All developers recapitulate the same model, that of the initial country. The presence of new technology and competition is an advantage, as it allows the latecomers to benefit from the skills and

\footnotetext{
${ }^{10}$ Ferdinand Enrique Candoso, “Associated Dependent Development: Theoretical and Practical Implications," in Alfred Stepan, ed., Authoritarian Brazil (New Haven: Yale University Press, 1973), and "Industrialization, Dependency and Power in Latin America," Berkeley Journal of Sociology, XVII (1972). The most frequently cited of Cardoso's untranslated works is that written with E. Faleto, Dependencia y desarrollo en America Latina (Santiago: Il Pes, 1967). An interesting "dependentdevelopment" literature on non-Third World countries has also developed, such as that on Canada. See Tom Naylor, "The Third Commercial Empire of the St. Lawrence," in Gary Teeple, ed., Economics and the National Question (Toronto: University of Toronto Press, 1972), pp. 1-42; Jeanne Laux, "Global Interdependence and State Intervention," in Brian Tomlin, ed. Canada's Foreign Policy: Analysis and Trends (Toronto: Methuen, 1978), pp. 110-135; Kari Levitt, The Silent Surrender (Toronto: Macmillan, 1970).

${ }^{17}$ For an excellent discussion of liberal "diffusion" and "dependencia" or colonial models, see Michael Hechter, Internal Colonialism (Berkeley: University of California Press, 1976).
} 
surplus of their predecessors. The question to ask according to the liberals, is not whether the relationship between core and periphery is unequal, but what would have happened to the latter without any contact with the former; to which the liberal reply is that the underdeveloped countries would have remained trapped in their condition. Of politics, liberal theorists say rather little except to deplore efforts to interfere with market forces.

For the other theorists, contact with the core may indeed be indispensable, but the results are not what the liberals claim. The nature of the industrializing process changes as the world economy evolves. New conditions require new models, new arrangements of people, resources, institutions, politics. There is no inherent reason why latecomers should develop the institutions of their predecessors (whose institutions were hardly uniform anyway). Indeed, there is every reason to suppose that the political systems of the newcomers must be different.

The liberals differ from their colleagues in a normative sense as well: they see the world economy as beneficial to all parties. The Gerschenkronian sensibility is more gloomy: good or bad, that is the way things are, and it is not clear what alternatives realistically exist. The dependencia theorists condemn the system; many of them believe alternatives are possible, generally in some form of socialism.

\section{The transnational relations, modernization and interdependence school}

A fourth category of theorizing about the impact of the international economy on domestic politics can be constructed from the authors writing on transnational actors and modernization in international relations. The spread of interdependence has led to the emergence of a distinctive phase in international relations, discontinuous from earlier ones for which traditional models of sovereignty were applicable; in this new phase, interdependence severely constrains the freedom of action of governments and even affects their internal organization. ${ }^{18}$

The roots of this outlook in the criticism of the "realist" paradigm are well known. In the mid-sixties the critique of realism centered on its view of the state as a unitary actor. Graham Allison's article set the pattern for a number of studies showing the conflict among various portions of the government over the determination of policy. ${ }^{19}$ In the seventies, the centrality of government itself in the formula-

\footnotetext{
${ }^{18}$ Robert Keohane and Joseph Nye, eds., Transnational Relations and World Politics (Cambridge: Harvard U.P., 1971), and Power and Interdependence (Boston: Little Brown, 1977); Edward Morse, Modernization and the Transformation of International Relations (New York: Free Press, 1976). For criticism, see Kenneth Waltz, "The Myth of National Interdependence," in Charles P. Kindleberger, ed., The International Corporation (Cambridge: MIT Press, 1970).

${ }^{19}$ Graham Allison, "Conceptual Models and the Cuban Missile Crisis," American Political Science Review LXIII (September 1970). Not surprisingly, these debates relate to changes in reality: realism dominated in a period of war and military confrontations; the easing of Cold War tensions and greater fluidity in international relations meant the system was less plausibly constraining, hence the disaggregating of the state through bureaucratic analysis; the salience of international economic issues in the seventies led to even further disaggregation, and even further downgrading of military and state-centered views.
} 
tion of foreign policy was the question. Nye and Keohane, Karl Kaiser, Edward Morse and others stressed the growing role of transnational, international and multinational actors, and global, non-military forces such as technology, trade, communications, and culture, in shaping policy. States were depicted as losing control over important issue areas, especially economic ones. Instead of explaining foreign policy, which is implicitly state-centered, the emphasis is on explaining "international regimes" in various issue areas, and not just the international system, which essentially stresses military power. Countries differ in these issue areas according to their "sensitivity" and "vulnerability" in various domains. In their most recent work, Nye and Keohane call this model "complex interdependence" and explore the conditions under which it, rather than other paradigms, is the most applicable. ${ }^{20}$

Complex interdependence alters domestic structures because it entails shifts in power away from certain governmental institutions toward other ones, or even shifts outside the government to private actors, or to international actors, or other foreign actors. Policy becomes the outcome of an immense swirl of forces, in which pieces of government become components along with companies, unions, pressure groups, international organizations, technology and so on. Patterns exist in these outcomes; the system is not totally anarchic, or at least, unlike the liberals, most of these authors do not wish it to be.

In their latest book, Nye and Keohane have become more cautious. "Complex interdependence" is not the paradigm of the present, but one model among others, whose applicability must be empirically determined case by case. Keohane and Nye accept quite readily that traditional models become more relevant on many issues, especially those involving conditions of considerable tension between countries, since military capability partakes more of the realist paradigm. The gains in applicability which come from these more limited claims are welcome but they reduce the uniqueness of the interdependence literature.

The interdependence argument has been taken farthest by Edward Morse in his recent book, Modernization and Interdependence. ${ }^{21}$ Morse sees the two as linked: modern societies are interdependent ones. Hence modernity through interdependence has altered the nature of the international system so much that the "anarchy" model of sovereign units loses its relevance. All modern societies in interdependent situations acquire certain common political characteristics such as strong welfare pressures, bureaucratization, legitimation problems which increase the relevance of domestic politics in foreign policy-making compared to the classic period of diplomacy. Thus the international and the domestic spheres become more important while the intermediate level, national government, diminishes.

\section{The neo-mercantilists and state-centered Marxists}

In strong contrast to the interdependence-modernization literature are the writings which assert the importance of the state in shaping responses to international

${ }^{20}$ Nye and Keohane, Power and Interdependence.

${ }^{21}$ Morse, Modernization and the Transformation of International Relations. 
forces. This literature does not deny that the international economic system constrains states, nor that the system affects the content of the policies which they formulate. Rather it challenges the tendency of some liberals, transnationalists, Marxists, and dependencistas to make the state wither away.

The leading neomercantilist formulation is Robert Gilpin's U.S. Power and the Multinational Corporation.$^{22} \mathrm{He}$ argues that governments of states have and assert some notion of national interest, be it power, stability, welfare, security, which is not reducible to the goals of any one group or coalition. These governments have the capability of acting in a coherent way, at least some of the time, in order to make their views prevail over those of other members of the polity. When the state chooses to act, its power is greater than that of any subunit, including such transnational actors as multinational corporations. In general, whenever states assert their views they are able to prevail over international organizations. Interdependence derives from state policy, not the other way around; that is, it exists because states allow it to exist. Should states refuse to do so, the constraining quality of that interdependence would be broken. All of these propositions are truer of some states than of others and vary according to the historical period. "International regimes" express the configuration of power. If a hegemonic power exists, the international economy will be open; in a multipolar world, economic nationalism and protectionism are more likely to prevail. States are constrained by the international economic system if they are not the hegemonic power. When there is no hegemonic power then all states are constrained by the system. Nonetheless, for the neomercantilists, the system leaves some latitude of policy response. At least for the larger states, the determination of that response, lies ultimately not in the hands of private actors but in those of the state.

Marxist writing on the international economy is generally criticized for an economic reductionist view of the role of politics and institutions. This is often true of the most frequently cited literature: Magdoff, Baran, and Sweezy. ${ }^{23}$ These writers tend to derive political behavior from strictly constructed economic exigencies: the drive to counteract falling profits, or to obtain resources critical to the operation of the defense technology of capitalist states, or to export domestic contradictions. The state is the instrument of the capitalist class.

Some recent Marxist literature has sought to set out a far less reductionist argument about the role of the state. The state is seen as having considerable autonomy from any one sector of the capitalist class or from any narrowly formulated economic goal such as procuring a particular resource or protecting a particular market. The state seeks to preserve the capitalist system, a tenet which makes these authors Marxists, but in order to do so it may have to do a great many things specific

\footnotetext{
${ }^{22}$ Robert Gilpin, US Power and the Multinational Corporation (New York: Basic Books, 1975); Gilpin, "Three Models of the Future," International Organization, 29 (Winter 1975): 37-60; Steven Krasner, "State Power and the Structure of International Trade," World Politics XXVIII (April 1976): 317-347, is not clear as to the balance between economic and military dimensions in the definition of a hegemonic power.

${ }^{23}$ Harry Magdoff, The Age of Imperialism (New York: Monthly Review Press, 1969); Paul Baran and Paul Sweezy, Monopoly Capital (New York: Monthly Review Press, 1968).
} 
sectors of the capitalist class do not like: welfare, nationalization, government intervention, unionization. Sometimes the capitalists have to be saved from themselves. Such "counter-class saviors" include FDR and Bismarck.

So far, these state-centered Marxists have not looked much at foreign policy. Instead they have concentrated on an explication of the limits of reformism in advanced capitalist societies. Insofar as this writing touches on foreign policy, it resonates quite harmonically with neo-mercantilist writings. Both attribute great importance to the international economy, with the mercantilists stressing power as a determinant of that economy, and the Marxists seeing the economy as basic. Both see the international economy as a powerful force field acting upon each country. Both see some leeway left to each country by that field, some range of choice. The choice is made politically, through a process in which the state plays an important role.

The most notable example of the influence of these ideas on international relations writing is Franz Schurmann's The Logic of World Power ${ }^{24}$ Schurmann pays attention to variables such as ideas, ideology, vision, bureaucratic rivalries, national traditions, group fragmentation, which are usually stressed by nonMarxists, but he seeks to relate these factors to the realm of interests, to economically grounded struggles for advantage among different classes and segments of classes or industries. Thus he seeks to specify the isomorphism of alternative views of America's world role (isolationism, internationalism, imperialism), with differing segments of American capitalism and to the process of acquiring and keeping political power. His view is not reductionist because none of these views is simply the epiphenomenon of class interest; politics and institutional structure matter greatly.

The difference between the neomercantilists and the state-centered Marxists lies not in their view of the autonomy of the state, in which they resemble each other more than does either of the other schools. Rather it lies in their view of the ends served by the state (national interest for the neo-mercantilists, partial interests for the state-centered Marxists) and in their conceptualization of the domestic forces with which the state must deal (groups for the former, classes for the latter). And of course the two differ normatively. The neo-mercantilists do not necessarily disapprove of the international economic order: their major concern tends to be with its stability (the need for leadership) and with the preservation of national values other than those desired by certain powerful interests within the state. Thus they can marshal criticism of oil companies with which the Marxists would take little exception. ${ }^{25}$ The state-centered Marxists value stability less and quite drastic change in both the capitalist and developing countries rather more.

On the role of the state, the interesting conflict at present is that between the neo-mercantilists, state-centered Marxists, and Gerschenkronians on one side and the liberals, the interdependencistas, and the economistic Marxists within the dependencia school on the other. The latter group tends to favor analyses either toward

\footnotetext{
${ }^{24}$ Franz Schurmann, The Logic of World Power.

${ }^{28}$ Steven Krasner, "The Great Oil Sheikdown," Foreign Policy 13 (Winter 1973-74): 123-138.
} 
disaggregation of the state or towards reductionism, either up to the international level or down to some other process such as economics; in all cases the state withers away.

The interdependence school and the dependencia argument bear a strong resemblance in another way: both seek to give an account of the international system and to derive state response from it. The difference between them, which will be further discussed in the final section, is the dating of this interdependence. For Nye, Keohane, and Morse, it is a part of modernity, especially since World War II. For Wallerstein it is at least half a millennium old.

\section{The international state system}

The arguments which impute great force to the international economic system in shaping the character of domestic political structures have been looked at thus far. The other major aspect of the international system to which similar capability can be attributed is the international state system. The anarchy of the international environment poses a threat to states within it: the threat of being conquered, occupied, annihilated or made subservient. The obverse of the threat is opportunity: power, dominion, empire, glory, "total" security. This state of war induces states to organize themselves internally so as to meet these external challenges. War is like the market: it punishes some forms of organization and rewards others. The vulnerability of states to such pressures is not uniform since some occupy a more exposed position than others. Hence, the pressure for certain organizational forms differs. The explanation for differential political development in this line of reasoning is found by pointing to differing external environments concerning national security.

The classic example of this argument (and for many other arguments as well) is the contrast between England and Prussia. As the English Channel sharply lessened the chances of invasion, England was spared the necessity of constituting a standing army and mobilizing national resources to sustain it. Instead, it was induced into maintaining a navy, an instrument of war with special characteristics regarding constitutional development. A navy cannot be used, at least not as easily as an army, for domestic repression. England's international security environment thus facilitated the development of a liberal, constitutional political order.

Conversely, Prussia's geopolitical location was very vulnerable. It was surrounded by a flat plain, here and there carved by easily fordable rivers. There was nothing natural about its borders, indeed nothing natural about the very existence of the country. It emerged in response to war, which also shaped its internal organization. In the seventeenth century, the Great Elector of Prussia persuaded the Estates to form a standing army with autonomous financing under his direct control, without supervision by representative bodies. This turned into the garrison state. The continual importance of military concerns gave the army and the Crown far greater influence than would have been the case had security-power issues mattered less. The consequences for German political development and German democracy are too well-known to need repeating. 


\section{Security arguments}

A classic statement of this argument can be found in Otto Hintze's "Military Organization and the Organization of the State." originally military organization, organization for war." 27

$\ldots$ in short, power politics and balance-of-power politics created the foundations of modern Europe: the international system as well as the absolutist system of government and the standing army of the Continent. England, with her insular security, was not directly exposed to the danger of these wars. She needed no standing army, at least not one of Continental proportions, but only a navy which served commercial interests as much as war aims. In consequence she developed no absolutism. Absolutism and militarism go together on the Continent just as do self-government and militia in England. The main explanation for the difference in the way political and military organization developed between England and the Continent-one which became more and more distinct after the middle of the seventeenth century-lies in the difference in the foreign situation. ${ }^{28}$

Hintze is quite explicitly critical of analyses of political development which focus exclusively on internal relationships. For the purpose of understanding those internal relationships he is most sympathetic to class analysis but he finds it insufficient, or underdetermining:

If we want to find out about the relations between military organization and the organization of the state, we must direct our attention particularly to two phenomena, which conditioned the real organization of the state. These are, first, the structure of social classes, and second, the external ordering of the states--their positions relative to each other, and their overall position in the world.

It is one-sided exaggeration and therefore false to consider class conflict the only driving force in history. Conflict between nations has been far more important; and throughout the ages pressure from within has been a determining influence on international structure. ${ }^{29}$

Hintze cites approvingly Herbert Spencer's interest in the importance of military and industrial pursuits in shaping social organization, but he criticizes Spencer for being too optimistic about the spread of commerce and industry.

In the four thousand years of human history that we look back over today there has been unquestionably a great increase in commercial activity but really no diminution in the readiness of states for war. ${ }^{30}$

\footnotetext{
${ }^{26}$ Otto Hintze, "Military Organization and the Organization of the State," in The Historical Essays of Otto Hintze, Felix Gilbert, ed. (New York: Oxford, 1975), pp. 178-215.

${ }^{27}$ Ibid., p. 181.

${ }^{29}$ Ibid., p. 199.

${ }^{29}$ Ibid., p. 183.

${ }^{30}$ Ibid., p. 130.
} 
This sentence is full of meaning for current discussions of interdependence and transnational relations.

A recent brilliantly formulated version of this argument can be found in Perry Anderson's Lineages of the Absolutist State. ${ }^{31}$ Anderson seeks to explain the emergence of absolutism in Western and Eastern Europe during the sixteenth and seventeenth centuries. In the West, he argues, absolutism was a response to a crisis of feudal relations generated from within. Following the contraction of population and economy in the fourteenth century, feudal economic relations started to crumble: labor dues were commuted to rents, trade revived, the use of land rationalized, and so on. These developments undermined the aristocracy's hold over life, particularly its dominance at the village level. Anderson sees absolutism as a means of protecting the aristocracy by recasting power upward. The centralized monarchies reestablished the nobility's privileged position, albeit in new ways and at the price of some concessions. The crown's new relationship to the nobles and other groups allowed it in turn some autonomy; it was able to undertake various kinds of modernizing tasks which the nobility might never have done on its own. Anderson thus fits in with the neo-Marxists discussed above who root the autonomy of the state in class relationships. In the sixteenth and seventeenth centuries, the crisis in Western Europe, and the responses, were fundamentally endogenous developments.

In Eastern Europe, Anderson contends, absolutism was exogenously induced. Market forces strengthened feudal labor relationships, instead of undermining them as in the West. Had this been the only stimulus, the aristocracy would have had no need for strong central government. Instead, the East was continually involved in war. The more advanced states of the West (Spain, France, Sweden, Holland, England), plus the great Turkish invasions from Central Asia, engaged the states and territories of Eastern Europe in an international state-system which forced them to adapt or sink. Prussia, Austria, and Russia generated centralized, absolutist regimes capable of fielding armies. Poland did not and was partitioned by these three neighbors in the eighteenth century.

Other recent examples of this type of argument include Stein Rokkan's essay "Dimensions of State Formation and Nation-Building," 32 and Samuel Finer's "State Building, State Boundaries, and Border Control." ${ }^{33}$ Rokkan connects his Parsonian model of state development ${ }^{34}$ with Albert Hirschman's "Exit and Voice" paradigm $^{35}$ to a wide variety of countries and situations. Finer relates these concepts explicitly to the cases of France and England. France developed absolutism as a way of preventing the constant impulse to exit. England lacked these centrifugal tendencies and was therefore able to allow a greater voice through parliamentarism.

\footnotetext{
${ }^{31}$ Perry Anderson, Passages from Antiquity to Feudalism and Lineages of the Absolutist State (London New Left Books, 1974).

${ }^{32}$ Stein Rokkan, "Dimensions of State Formation and State-Building," in Charles Tilly, ed., The Formation of National States in Western Europe (Princeton: Princeton U.P., 1975), pp. 562-600.

${ }^{33}$ Samuel Finer, "State Building, State Boundaries and Border Control," Social Sciences Information, 13 (4/5): 79-126.

${ }^{34}$ Stein Rokkan and S.M. Lipset, "Introduction," Party Systems and Voter Alignments (New York: Free Press, 1967).

${ }^{35}$ Albert Hirschman, Exit, Voice, and Loyalty (Cambridge: Harvard U.P., 1970).
} 
The special nature of foreign relations

War has always loomed large in the concerns of political theorists. We usually read them as giving models of organized life within a community, or polis, or state. For some, such as Hobbes, accounts of life without a sovereign are taken as models of the international system. It has always been understood that foreign relations poses special problems with implications for the organization of the state. The point of Machiavelli's maxims was to help the Prince unite Italy. Bodin's discussion of sovereignty considered how to allow the Crown to defend the state without escaping the rule of law altogether. Defense of the realm was quintessentially that function which required a single sovereign; it required speed, authoritativeness, secrecy, comprehensiveness. These attributes were beyond the reach of representative assemblies. Hence, involvement in the international system inevitably meant more power to the Crown. This was precisely the argument put forward by some American isolationists. "Foreign entanglements" threatened democracy at home by upsetting the balance of power in favor of the presidency. The same critique of imperial conquests was made in ancient Greece and Rome and returned to the United States during the Vietnam War. ${ }^{36}$

\section{State building as foreign policy: territorial compensation}

Another way the international state system can affect political development is through the deliberate actions of one state upon another, such as territorial compensation. Prussia-Germany rose and fell because of this. From the sixteenth to the nineteenth centuries, France promoted fragmentation in Central Europe as a means of resisting Hapsburg encirclement. She wanted no concentration of power near her borders. Prussia was one of the beneficiaries of that policy, being weak originally and far from the Rhine. France gave territory to Prussia in order to build a counterweight to Austria, buffered by Saxony, Hanover, Palatinate closer to the French border. Without the territorial grants given at the Peace of Westphalia, the Treaty of Utrecht, the Peace of Paris, and the Congress of Vienna, Prussia could never have become the Frankenstein monster which turned on its benefactor. An unfortunate choice of allies at key moments undermined the ability of Bavaria and Saxony to contest Prussian leadership in the nineteenth century. And, quite obviously, international politics explains the dismemberment of Germany after 1945, and the character of the two regimes which have grown up in the East and the West. ${ }^{37}$

\section{The strains of foreign involvement}

Finally, those arguments should be noted which examine the strain that the international state system imposes on domestic society as a whole. This is most evident in the study of revolution. The English, French, Russian, and Chinese

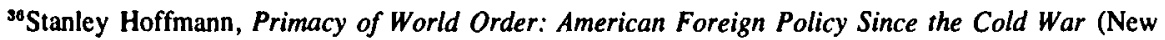
York: McGraw Hill, 1978).

${ }^{37}$ Karl Kaiser, German Foreign Policy in Transition (London: Oxford U.P., 1968).
} 
Revolutions all began with some international disturbance that overtaxed the political system. For the English, it was the need to fight a war with Scotland; in France, involvement in the American Revolution; in Russia, the defeats of World War I; for China, the Japanese invasion during World War II. The Civil War was America's nearest equivalent to a revolution in its impact upon society and institutions. ${ }^{38}$ The outbreak and outcome of these revolutions is unintelligible without an examination of international factors. At present, Israel, Lebanon, and the Arab states offer obvious examples of the impact of these forces.

\section{Part two: domestic structures and the international system}

Thus far arguments have been presented which discuss the effect of international politics on domestic politics. While the arguments differ widely in the type of relationship posited, in tightness and plausibility, there is certainly enough to suggest that students of comparative politics treat domestic structure too much as an independent variable, underplaying the extent to which it and the international system are parts of an interactive system.

In this section, I return to the traditional question: which aspect of domestic structure best explains how a country behaves in the international sphere? The only type of argument which would render that question unnecessary is one which derived domestic structure completely from the international system. This is a thoroughly nonreductionist approach (in Waltz's language) ${ }^{39}$ and arguments of that type are not totally convincing. The international system, be it in an economic or politico-military form, is underdetermining. The environment may exert strong pulls but short of actual occupation, some leeway in the response to that environment remains. A country can face up to the competition or it can fail. Frequently more than one way to be successful exists. A purely international system argument relies on functional necessity to explain domestic outcomes; this is unsatisfactory, because functional requisites may not be fulfilled. Some variance in response to external environment is possible. The explanation of choice among the possibilities therefore requires some examination of domestic politics.

Prussia and Poland, for example, both occupied similar positions in relationship to world economic forces and similarly vulnerable security positions. The one developed a powerful military absolutism which eventually conquered its linguistic neighbors to form Germany. The other gave rise to the liberum veto, a large eighteenth century literature on defective constitutions, and was partitioned. The difference has to do with internal politics. Thus the formation of regime type and coalition pattern requires reference to internal politics.

\footnotetext{
${ }^{38}$ See the excellent study by Theda Skocpol, "France, Russia, China: A Structural Analysis of Social Revolutions," Comparative Studies in Society and History 18 (April 1976): 175-210. See also her book on revolutions to be published by Oxford University Press.

${ }^{30}$ Kenneth Waltz, "Theory of International Relations." By non-reductionist, Waltz means an explanation of international politics at the system level, third rather than second image. Here I am extending the word to distinguish between endogenous and exogenous explanations of regime type.
} 
So do most of the categories used in discussing regime type or domestic structure. The international relations literature contains numerous arguments about the importance of domestic structure. The debate has centered around which aspect matters most: the presence and character of bureaucracy (Kissinger, Allison, Halperin); the pressure of the masses on policy making or the lack of such pressure (Kissinger, Wilson, Lenin); the strength and autonomy of the state (Gilpin, Krasner, Katzenstein); the drives of the advanced capitalist economy (Lenin, Magdoff, Baran, and Sweezy); the perceptual set of leaders (Jervis, Steinbrunner, Brecher); national style (Hoffmann); the logic of industrial development (Kurth); the character of domestic coalitions (Gourevitch, Katzenstein); the relative weight of transnational actors in a given polity (Nye and Keohane); the level of modernization (Morse). ${ }^{40}$

Having gone through the exercise of Part one helps bring out a deficiency in many of these arguments or present formulations of them. Many arguments focus on process and institutional arrangement divorced from politics; on structure in the sense of procedures, separate from the groups and interests which work through politics; on the formal properties of relationships among groups, rather than the content of the relations among them; on the character of decisions (consistency, coherence, etc.) rather than the content of decisions. Somehow politics disappears. Clearly, a careful defense of such broad assertions would require an examination of each of the arguments about which I am critical. There is no space to do that here. Instead, I shall consider one example, chosen because it deals with foreign economic policy, an area in which I have worked. The line of argument to which I refer is that which uses as a major explanatory variable state strength " "strong states" vs. "weak states," or "state-centered policy networks" vs. "society-centered policy networks"). ${ }^{41}$

The strong state argument goes something like this. In societies with strong states, or state-centered policy networks, policy-formation corresponds to the model of unitary government: the state, emanating from the public or some other sover-

\footnotetext{
${ }^{40}$ Besides works already cited, see: Robert Jervis, Perception and Misperception in International Politics (Princeton, N.J.: Princeton U.P., 1976); John Steinbrunner, The Cybernetic Theory of Decision: New Dimensions of Political Analysis (Princeton, N.J.: Princeton U.P., 1974); Michael Brecher, The Foreign Policy System of Israel: Setting, Images, Processes (New Haven: Yale U.P., 1972); Michael Brecher, Decisions in Israel's Foreign Policy (New Haven: Yale U.P., 1975). See also R. Harrison Wagner, "Dissolving the State: Three Recent Perspectives on International Relations," International Organization 28 (Summer, 1974): \$35-466.

"Stephen Krasner, Raw Materials Investment and American Foreign Policy (Princeton: Princeton University Press, forthcoming); Peter Katzenstein, "Introduction" and "Conclusion" to "Between Power and Plenty: Foreign Economic Policies of Advanced Industrial States," International Organization 31 (Autumn 1977) and "International Relations and Domestic Structures: Foreign Economic Policies of Advanced Industrial States," International Organization 30 (Winter 1976); Stanley Hoffmann, "The State: For What Society,"' Decline or Renewal (New York: Viking Press, 1974); Bruce Andrews, "Surplus Security and National Security: State Policy as Domestic Social Action," International Studies Association, Washington, D.C., February 22-26, 1978. John Zysman has some astute comments about the connection between institutional form and the content of policy toward international competition in his study of the French electronics industry: Political Strategies for Industrial Order (Berkeley: University of California Press, 1977).
} 
eign, formulates policy which is an articulation of collective interests. The state speaks on behalf of goals broader than those of any particular group. Its unitary structure allows it to impose that policy over the objections of particularistic interests.

In societies with weak states (or society-centered policy networks) policyformation corresponds to a model of pluralistic government: social forces are wellorganized and robust. Public institutions are fragmented; power is formally distributed among a large number of interdependent but autonomous agencies. These pieces of the state are captured by different private interests, which are then able to use them to exercise veto power over public policy or even to acquire a complete control over public policy in a given domain. Policy is the outcome of the conflict among these complex public-private linkages. The United States is obviously the most commonly cited exemplar.

The prevalence of one or the other type of state or network can be explained historically: different state-society relationships prevailed in the process of modernization. However similar countries have become in other respects, these differences persist and remain relevant. The nature of the network or state structure explains, according to this school, key aspects of foreign policy. In several remarkably comprehensive essays, ${ }^{42}$ Peter Katzenstein argues, for example, that United States foreign economic policy is less consistent and more dominated by economic considerations than is French policy, which tends to have more coherence and to reflect political preoccupations about France's position in the world. More recently, he has contrasted the market orientation of American, British, and German policy with the dirigiste orientation of the French and Japanese.

Lacking space for careful examination of each of the countries, let me evoke the problems with such argumentation through two examples, one concerning a "weak state" country, the other concerning a "strong" one. Katzenstein, Krasner, and other authors propose that in the United States, protectionists' interests are strong in Congress, while free trade interests are stronger in the executive. The shift from protection to free trade after World War II thus required and was facilitated by the shift in power from Congress to the presidency. That the presidency grew in power and that it favored free trade while protectionists squawked in Congress I do not dispute. Was the policy change, though, caused by a shifting balance of institutions or were both symptoms of something else? The argument implies that had the presidency somehow managed to acquire power earlier there would have been a shift in United States commercial policy. I find that dubious. The United States and many other countries with widely differing political forms, strong and weak states alike, pursued protectionist policies from the 1870s through 1945, with few interruptions. Would Congressional dominance have prevented the shift to free trade after World War II? I doubt even that. A great many American interests were shifting to free trade. Perhaps the votes in Congress would have been closer, but would the outcome have been so different?

${ }^{42}$ Katzenstein, International Organization articles. 
For France, the strong state argument requires us to think that it matters little who controls the state; the fact of having a state-centered network becomes more important than the question of the political orientation of the government. Thus the change from the Fourth Republic to de Gaulle did not matter, this argument implies, since the bureaucracy ran the show in both, as presumably it did under the Third Republic. Is that plausible? Would the same be true if the Left had won the legislative elections of 1978 ? Would there be no policy change because the strong state network remains in place, because the state-society balance remains the same? Or would it change because the state machine was now in the hands of persons with different policy goals? Even continuity in policy would be hard to interpret. Should the Left coalition turn out to be prudent and cautious, pursuing policies not different from Giscard's, would that be because the state machine constrained it, or because the coalition feared flight of capital, an investor's strike, foreign pressures, labor militancy, voter discontent: in short, politics of a similar kind, regardless of this strong-weak state distinction? The strong state-weak state argument suggests that the type of relation predominates, hence the identity of the governing coalition does not matter. This is a very apolitical argument.

The basic problem with this line of reasoning is that it provides no explanation for the orientation of state policy in the supposedly state-dominated countries. The advantage of looking at politics and the state is that it helps us get away from the well-known problems of pluralist or Marxian reductionism: policy is not simply traceable to the interests of one or another group. First, powerful groups conflict among themselves. Second, the interaction among groups is affected by structures. Third, politicians and bureaucrats who run the state have some leeway. Hence, the importance of politics and the state. But the notion of a strong state as presently used escapes from this trap at the cost of heading into another: instead of explaining society (where the groups get their orientations, why some are stronger than others) we have to explain the state. Why does the state go in one direction rather than another? Why does it articulate a particular conception of the national interest over another? Why does it use its leverage over particular groups in some ways and not others? Why doesn't the French state use its power to bring about workers' control, equality of income distribution, stricter pollution control? Why does it support traditional and small industries? Why does it also promote concentration of industry? How does it choose between the claims of small and large enterprises? Any policy pursued by the state must be able to elicit the support of at least enough social elements to sustain the state leaders in power. Hence explanation of the orientation of state policy requires some examination of the politics behind state action. To speak of the strong state suggests that politics can be taken out of the equation for some states and not for others. The action of the strong state depends as much on politics as does that of the weak one.

Ignoring politics in fact shapes the discussion in a way those interested in the type of state would presumably dislike. The argument reverts to explanations involving a rational actor, or at least a unitary actor model of the state, and towards realist type reasoning about the state, in which the state becomes a unitary actor. If 
there is no conflict, latent or actual, about the proper course of policy, and if there is no disagreement about what public power should be used for, then the state or the network become wholes, responding in a collective way to external stimulants. The analysis of foreign policy is then reducible to the examination of the international system. If, on the other hand, conflict within each country exists, then the consequences of having a particular type of state must be linked with the political struggle for one or another policy option. If there is little or no conflict over policy, that too requires explanation. Such constraint could be derived from a range of causes: the logic of an international situation (back then to rational actor analysis), or the logic of market capitalism (which then requires an analysis of how and why it has influence, something usually only the neo-Marxist literature is interested in showing). ${ }^{43}$

I do not wish to argue that the character of the state structure or the "policy network" has no impact on policy. On the contrary, by setting down the rules of the game, institutions reward or punish specific groups, interests, visions, persons. These effects can be seen case by case, as in the Cuban missile crisis, or over a whole pattern of cases, such as tariff policy. But the impact of structures lies not in some inherent, self-contained quality, but rather in the way a given structure at specific historical moments helps one set of opinions prevail over another.

Structure affects the extent to which a governing coalition must make sidepayments to build up its strength, the extent to which it can impose its views. It affects the possibility of realizing certain policies. Examples abound. The types of taxes the Italian state can raise are limited by the weakness of the state bureaucracy; the types of industrial policies Britain can pursue are limited by the fragmented character of banking and industry; French dirigisme is surely facilitated by the position of the grand corps there; American energy policy is not likely to be some carefully orchestrated scheme which must get through Congress in toto or not at all. In each case, the effect on policy derives from the voice given by structures to some point of view: relatively fragmented, or open political systems increase the number of veto groups; relatively unitary, or closed systems, do not eliminate veto groups or bargaining but only limit their range. Whoever controls the state in unitary systems has an easier time passing laws, though whether this makes the formation of policy "easier" is not clear. Witness Britain. ${ }^{44}$

What the strong-weak state distinction does, along with many other structural categorizations, is to obscure important ways in which politics, our central subject matter, shapes outcomes. It thereby encourages various forms of reductionism. The need to secure support for a policy affects its final content. Majorities have to be built, coalitions constructed, terms of trade among alliance partners worked out, legitimating arguments developed, and so on. These tasks impose constraints on

\footnotetext{
${ }^{43}$ Peter Bachrach and Morton Baratz, "Decisions and Non-decisions: An Analytic Framework," American Political Science Review 57 (1963).

${ }^{44}$ Whether being open or closed, or having strength or weakness can be systematically linked to the content of politics is much less clear. Attention to such variables makes the most sense in looking at the characteristics of decisions other than their actual content: coherence of a series of decisions, say, about tariffs, rather than the actual level.
} 
groups, constraints which cannot be understood either by examining them separately, which is the characteristic shortcoming of reductionist liberal or Marxist argumentation, or by examining the structures through which they work or even the properties of the relationships among them, which is the characteristic shortcoming of the authors I am criticizing here.

This idea is captured in the old concept of logrolling: the need to make bargains changes the outcome. The importance of organizations, political parties, elections, ideologies, vision, propaganda, coercion and the like as well as the more obvious aspects of economic interest arise from this need. What must be illuminated is how specific interests use various weapons by fighting through certain institutions in order to achieve their goals. Each step in this chain can affect the final result. We may call this sort of argument "coalitional analysis" since it seeks to explain policy through investigation of the content of group interests and the efforts to form alliances among them.

"Coalitional analysis" enables us to see how the process of getting a policy adopted affects its content. In analyzing Bismarck's foreign policy, for example, Hans-Ulrich Wehler stressed the importance of domestic policy goals in the foreign maneuverings, der Primat des Innenpolitik over Aussenpolitik. ${ }^{45}$ Bismarck confronted a wide range of social forces disgruntled with the empire which he had constructed: liberals, constitutionalists, socialists, Catholics, particularists. To keep this opposition divided and to rally some of its members to the conservative side Bismarck manipulated nationalism and imperialism. Foreign policy crises were repeatedly used, argues Wehler, as the ideological glue for the diverse coalition that kept him and the system that he constructed in power. Again the fault in a purely structural argument is evident: the machinery which gave Bismarck power was itself a political creation. Politics could bring it down, hence it was not an independent variable.

Paul Smith makes a similar argument concerning Disraeli and the Conservative Party. ${ }^{46}$ The sentiment for empire helped provide the means for linking up landed squires, businessmen, rural laborers and working men, whose differences on matters such as tariffs, democratization, and socialism were large. In the United States, rivalry with the Soviets was used in the late 40 s and early 50 s to justify purges at home against leftists in unions, universities, government, and business. ${ }^{47}$ The Soviet Union uses this rivalry to control dissidents today.

In all of these examples, a plausible case can be made for the importance of structures. I do not wish to assert that one or the other mode of analysis must in principle always be correct. We are likely to find, as in all interesting cases,

\footnotetext{
${ }^{45}$ Hans-Ulrich Wehler, "Bismarck's Imperialism, 1862-1890," Past and Present 48 (1970): 119-155. Leopold Ranke is the most noted exponent of the primacy of "foreign policy" school. See Theodore von Lave, Leopold Ranke, The Formative Years (Princeton: Princeton U.P., 1970). Also the comments by Morse in Modernization and the Transformation of International Relations.

${ }^{46}$ Paul Smith, Disraelian Conservatism and Social Reform (London: 1967); Robert Blake, Disraeli (New York: 1966). Miles Kahler, "Decolonization: Domestic Sources of External Policy, External Sources of Domestic Politics," Ph.D. Thesis, Harvard University, 1977.

${ }^{47}$ Franz Schurmann, The Logic of World Power.
} 
multiple causation, or several factors producing a given result, so that it becomes hard to sort out which does what. Take American and French energy policy: the state plays a much more active role in France directing the securing of adequate supply, import, marketing, pricing and other aspects than does the state in the United States. The French state plays a greater role in handling French relationships with other countries concerning energy. France goes farther in placating Arab opinion. France is also much more dependent than the United States on oil, has a much less well developed energy industry, and fewer private companies. The relationship of the state in France to the issue area is thus completely different. The connection to society, the outside world, and strategic and economic concerns differ radically between the two countries. Could not those differences explain a good deal of the dissimilarity between French and American energy policy and the very role of the state itself? The perfect test of the consequences of structure (which is rarely realizable) is to find two countries with similar positions or interests in relationship to some policy area but with differing political structures; if the policy is the same, structures do not matter; if the policies differ, structures may well be the explanation. I tried to test this by examining tariffs in the late nineteenth century, and I concluded that structures mattered much less than the prominent differences of the German, British, French, and American political systems might lead one to suspect. Carter's efforts to put through an energy program give us only a weak test: the separation of powers clearly imposes obstacles on comprehensiveness and strengthens the leverage of the lobbies. Cabinet governments have an easier time. But it is also true that the dangers to the American economy of having no comprehensive energy policy are also not yet overwhelming, certainly not in comparison with some European countries. Since the situation is so different, we cannot be sure what produces the different result. The same logic can lead to different results operating in different situations. Katzenstein stresses the differences in structure; I would stress those in situation.

While these arguments cannot be settled definitively, care can be taken to be clearer about what is being argued. I suggest that we require more stringent tests of the various positions. Given my proclivities, the tests I suggest are framed with the strong-state weak-state argument in mind. Arguments for the importance of state form in explaining foreign economic policy should deal with the following questions:

1. What is the position of the country being studied in relation to the world economy? That is, what position on the policy issue would we expect it to have given some view of its interests? (E.g., oil producers want higher prices.) If the country's policies are in accordance with that expectation, there is no reason to elevate "state structure" above "interest" as an explanation.

2. Within the society, whom does the policy benefit? Who supports it? Who opposes it? Does actual policy correspond with the wishes of a significant coalition of interests? If so, there is again no reason to prefer "state structure" to either conventional "group politics" or "Marxist reductionism" as an explanation. When policy and the interests of the strongest coincide, it is not clear that the state has produced the result. Politics and structure may help one group of interests defeat 
another. It is certainly important to ask: what levers do structures give various interests in policy battles?

3. Who defines the policy alternatives, both the ones debated and the ones adopted as policy -officials of the state, politicians and civil servants, or agents of non-state actors, business, union, voluntary association leaders? If the policy is formulated outside the state apparatus, that is evidence for the state as "instrument." 48 If the policy is formulated inside the state apparatus, a certain prima facie case has been made for the importance of that apparatus.

4. How is the policy "legitimated?" What makes the policy politically successful? What is the political status of alternative policies? Whose opposition could block the policy? Whose opposition could impose severe political costs on those who seek that policy? Is the state able to impose the policy, and upon whom--a firm, an industry, a sector of the economy-and how - by inducement, coercion? What kinds of opposition are possible-electoral, strike of labor, strike of capital? Here is the weakest link in the state-centered arguments. Even state coercion requires someone's backing, be it that from the secret police or others. In each case a political explanation of support is required.

An attempt to answer these questions should heip to clarify this argument. Without doing so, the difficult cases where state behavior and the wishes of a dominant group appear to coincide cannot be unravelled. Katzenstein notes that in his cases of "state-centered" policy networks, France and Japan, there is considerable symbiosis between business and the state. Discussions, interchange, cooperation, and so on are extensive. Who has coopted whom? Is the relationship between business and the state in Japan similar to that between the airline industry and the Civil Aeronautics Board in the United States? If so, it hardly makes sense to characterize Japan as having a strong state or a state-centered policy network. Nor does it make sense to say that the United States has a weak state, because, after all, the American state is capable of enforcing the CAB's regulations to prevent competition. A weak state would be unable to do so.

This critique of state-centered arguments is not a critique of the role of politics or institutions. I am not offering some sort of reductionist argument pointing to business determinism. Reductionism is not the only alternative to structure. Showing how politics and institutions affect struggles between social forces is also possible and preferable.

\section{Part three: international relations and domestic politics: why talk about interdependence?}

It is a startling experience to have read within the space of a few months Edward Morse's Modernization and International Relations, Immanuel Waller-

\footnotetext{
"See the very interesting and growing neo-Marxist literature on the state such as: Fred Bloch, "The Ruling Class does not Rule: Notes on the Marxist Theory of the State," Social Revolution 33 (May-June 1977): 6-28; David Gold, Clarence Lo, and Erik Olin Wright, "Recent Developments in Marxist
} 
stein's The Modern World System, and Perry Anderson's Lineages of the Absolutist State. On several critical points, the first completely contradicts the other two. In other ways, all three express a similar consciousness.

Morse's book is an exemplar of recent interdependence literature and arguably the best of it in that it is the most comprehensive historically and theoretically. The interdependence-transnational school argues that modernization among states creates a fundamental discontinuity in the nature of international relations. First, interconnectedness means that structured linkages among states exist; hence traditional models of the system based upon anarchy as the essential characteristic of the international environment have diminished relevance. Second, interdependence means that various elements of domestic society are linked to each other through international forces; hence, traditional models based upon a sharp distinction between foreign and domestic politics, and upon the primacy of the state, have diminished relevance. These features of world life may have existed before, but it is only in the modern period (which, alas, Morse never defines too clearly-is it since 1789? 1914? 1945?) that quantity produces qualitative change, and thus alters the essence of international relations.

In the world Anderson and Wallerstein analyze, however, all of these presumably modern features existed in extremely powerful forms four centuries ago. Trade and war were already shaping every conceivable aspect of both domestic politics and the international system. Foreign and domestic politics were hopelessly interpenetrated. Despite my criticisms of the sufficiency of Wallerstein's and Anderson's arguments as accounts of the determination of the specific type of emerging states, their effort to start the analysis of the interaction back at the beginning of both state and interstate relations is convincing.

In the sixteenth century, after all, the question of whether the King of France should be Catholic or Protestant provoked a civil war in which foreign intervention was every bit as massive as it was during the Spanish Civil War, or the Russian Revolution, or even Vietnam 350 years later. The same hopelessly interpenetrated quality of foreign and domestic issues was also present in the Revolt of the Netherlands, the Thirty Years War, and indeed all the wars of the sixteenth and seventeenth centuries.

During the War of the Spanish Succession, the Duke of Marlborough had constantly to confront unstable domestic backing for his armies and policy; the electoral victory in 1710 of the backwoods squires (the isolationists, worried about taxes and the Church, resentful of expensive foreign adventurism - the appeasers of the day) over the Whig magnates (the internationalists, the interventionists, the anti-appeasers, who were interested in foreign trade, continental equilibrium, stopping French hegemony) was a godsend to Louis XIV. The new government leashed

Theories of the Capitalist State," parts 1 and 2, Monthly Review (October and November 1975); Klaus Offe, "Structural Problems of the Capitalist State," Klaus von Beyme, ed., German Political Studies, (Beverly Hills: Sage, 1976); Klaus Offe and Volker Ronge, "Theses on the Theory of the State," New German Critique 6 (Fall 1975); James O'Connor, Fiscal Crisis of the State (New York: St. Martin's Press, 1973). 
Marlborough (preventing him from carrying the war to Paris) and negotiated a peace far more beneficial to the French than was thought possible a few years earlier.

What of Prussia, supposed paradigm of the distinction between foreign and domestic policy? The existence and power of Prussia depended on military organization and hence on domestic politics. The whole thrust of Gordon Craig's excellent book is to show how repeated cycles of the army's estrangement from the rest of society gravely weakened Prussia politically and militarily.$^{49}$ Repeatedly, the political system and the army had to be opened up, new elements let in, and meritocracy rewarded. Such was the meaning of French dominance between 1789 and 1815: social organization changed military capacity. War forced the Prussians to reform. Stein Hardenberg made the defeat of Napoleon possible. The conflict over the Army Indemnity Bill in 1862 and the subsequent wars leading to German unification in 1870 show as thorough an interpenetration of constitutional, economic, military and security issues as one can find before or since. And war among "modern" countries can hardly be said to have disappeared.

What of international trade? The shift in trade routes from East to West in the fifteenth and sixteenth centuries undermined towns, altered the social balance, and contributed to the enserfment of the entire East European peasantry. The pull of Dutch markets induced sheep farming in southern England, which in turn spurred the decomposition of feudalism (enclosures, commutation of dues, driving peasants off the land, crumbling of guilds, etc.) which became one of the central cleavages in the English Civil War. At the height of the Civil War, despite two centuries of cooperation before and afterward concerning opposition to the Catholic-SpanishFrench hegemony, Britain and Holland took time to fight a series of naval wars for control of international trading. One could argue that in some of these examples policy affected relatively small numbers of people in each country, though hardly in the case of serfdom vs. the collapse of feudalism. Surely by the nineteenth century, this was no longer true. England's factories devastated the Indian textile economy. What does the international-domestic distinction mean in the fight over the Corn Laws, Cobden-Chevalier, or the German, French, Italian, American, Canadian, Australian, Russian tariffs after 1873 ?

In other respects the present is not so different from the past. Despite interdependence, the state retains its ability to control transnational actors, if it is able to muster the political support for doing so. The Soviet Union and China depend on the world for many things, but they control far more strictly than the Western countries the terms on which they interact. In the case of Russia surely that is not because it is less modern than the West, but because its political system is different. The Western states could do the same but do not.

Bureaucratic politics, interdependence, interpenetration, transnational forces and actors-seem as relevant for an analysis of the past as they do for the present. Louis XIV, Frederick the Great, and Wallenstein could be looked at using these concerns. International anarchy, security, and state power all seem relevant to the present as well as to the past.

${ }^{49}$ Gordon Craig, The Politics of the Prussian Army (Oxford: Oxford U.P., 1964). 
I am not suggesting that the present has no unique features: the United Nations and the atom bomb are by far the most distinctive. The latter marks a qualitative change in international relations by confusing the relationship between the existence of power and its use. The global economy is certainly more extensive and dramatic than anything previously witnessed. But is it more than the extension of the Roman model to the whole world? Every period has its distinctive features. Why assert a discontinuity? The most useful thing the interdependence school has done is to work out models based on principles other than anarchy. Having these allows us to compare different periods. Reality will, as usual, prove confusing. It will be hard to settle arguments in any clean or definitive way, about whether we have moved from one model to another, and when.

When reality is too confusing to settle arguments, posing a question in the sociology of knowledge becomes interesting and relevant: the striking thing is that very diverse authors who read very little of each other should be asking similar questions about widely different periods. Wallerstein wants to know about interdependence in the sixteenth century; Morse about the same thing in the twentieth. Why are they looking for the same thing? Why doesn't someone do a bureaucratic politics study of Marlborough or Napoleon?

The answer is certainly different for each school of authors, but in both cases it is marked by deeper issues of value and political outlook. This is not meant as a criticism, implying that these authors should have purged such elements from their work. Complete value neutrality is unrealizable. Values and the politics connected to them should be discussed openly, and it is always important to have a sense of what values inform various works.

For the interdependence-modernization school, the central concern appears to be with the dangers of anarchy: one might say that they reject the relevance of anarchy because they fear it. Since the world is new, there are new requirements for its maintenance. Leadership is necessary. The United States is the only power capable of providing it. It should do so. Such leadership is not imperium, since imperium is a concept which applies to the unneeded hegemony of one power over others. Now interaction is inescapable; the issue is not whether it exists, but how it is to be managed.

For the dependencia school, the central concern appears to be the dangers of interdependence in its capitalist embodiment. They reject it because it is seen as incompatible with socialism. Interdependence is linked to capitalism, and capitalism is old; therefore interdependence goes back a long way. In its market forms, it prevents societies from developing as they see fit, rather than according to the needs of the capitalist system. These theorists worry about the Third World, although a subset of them does make the link back to the core; participation in the system corrupts the master as well. Interdependence was an element of capitalism neglected by Marxian and other theorizing which treated states and national trajectories of development as separate. The explication of the possibilities of socialism, as well as the dangers, therefore requires analysis of the progress of interdependence, of the constraints which it imposes. 
I am personally part of that group which is sympathetic to both concerns. If hegemony has its nefarious consequences, so does economic and political nationalism. Leadership is useful but easily perverting and pervertible. But this has always been true. Interdependence is an old reality, as is anarchy. The argument ought to be about how interdependent-anarchic situations differ, not whether they are new.

\section{Part four: conclusion}

The relationship among the three parts of this paper may be summarized as follows: The international system is not only a consequence of domestic politics and structures but a cause of them. Economic relations and military pressures constrain an entire range of domestic behaviors, from policy decisions to political forms. International relations and domestic politics are therefore so interrelated that they should be analyzed simultaneously, as wholes.

However compelling external pressures may be, they are unlikely to be fully determining, save for the case of outright occupation. Some leeway of response to pressure is always possible, at least conceptually. The choice of response therefore requires explanation. Such an explanation necessarily entails an examination of politics: the struggle among competing responses.

The interpenetrated quality of international relations and domestic politics seems as old as the existence of states. There is therefore no reason to associate different modes of explanation for differing periods according to the degree of interdependence. 


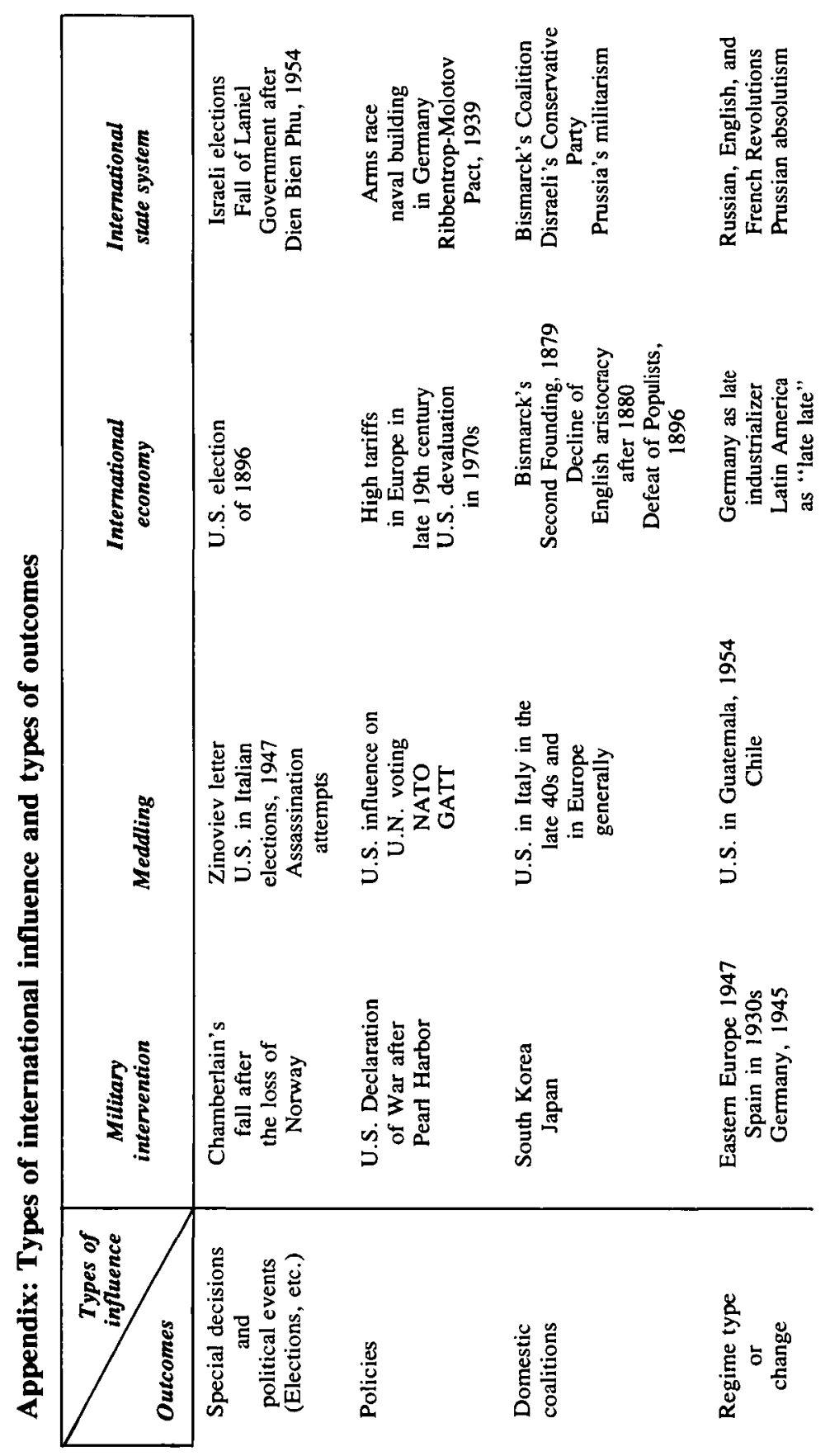

